\title{
STRATEGI PEMBELAJARAN PEMANFAATAN BANK SAMPAH GALANG PANJI SEBAGAI MEDIA PENDIDIKAN KARAKTER DALAM PEMBELAJARAN IPS DI SMPN 4 SINGARAJA
}

\author{
Oleh : \\ Tini Agustini' ${ }^{1}$ I Made Tegeh ${ }^{2}$, \\ ${ }^{1}$ SMKN 2 Singaraja' ${ }^{2}$ Jurusan Teknologi Pendidikan \\ Universitas Pendidikan Ganesha \\ e-mail : tiniagustini56@gmail.com ${ }^{1}$, imadetegehderana@yahoo.com ${ }^{2}$,
}

\begin{abstract}
ABSTRAK
Tujuan penelitian ini adalah mendeskripsikan strategi pembelajaran pemanfaatan Bank Sampah Galang Panji sebagai media pendidikan karakter dalam pembelajaran IPS di SMP Negeri 4 Singaraja. Jenis penelitian ini adalah penelitian kualitatif. Lokasi penelitian adalah SMPN 4 Singaraja, Kabupaten Buleleng, Provinsi Bali. Adapun informan kunci penelitian ini adalah guru dan siswa SMPN 4 Singaraja. Dalam penelitian ini sampel penelitian ditentukan berdasarkan teknik purposive sampling. Metode pengumpulan data yang digunakan dalam penelitian ini adalah wawancara dan kuesioner,. Data dianalisis secara kualitatif dengan mengikuti beberapa tahapan seperti reduksi data, menyajikan, menafsirkan, dan menarik kesimpulan. Hasil penelitian menunjukkan bahwa pengimplementasian Bank Sampah Galang Panji sebagai media pendidikan karakter dalam pembelajaran IPS di SMPN 4 Singaraja dilakukan secara terintegrasi.Terdapat enam strategi yang dapat dilakukan untuk pengimplemenntasian bank sampah sebagai media pendidikan karakter.
\end{abstract}

Kata-kata kunci: strategi pembelajaran, bank sampah, media, pendidikan karakter

\begin{abstract}
This research is aimed to describe the instructional stategy of "GalangPanji" waste bank as a character building education media of social science at SMPN 4 Singaraja. This research is a qualitative research. This research took place at SMPN 4 Singaraja, Buleleng Regency, Bali Province. The informants of this research were teachers and students of SMPN 4 Singaraja. The sample of this research was determined by using purposive sampling technique. The methods of data collection which were used in this research, namely interviewand questioner. The data were analyzed qualitatively by following the steps, reducing, presenting, predicting, and concluding the data. The results of this research were the instructional strategy of "GalangPanji" waste bank as a character building education media of social science at SMPN 4 Singaraja was done in integrated
\end{abstract}

Strategi Pembelajaran Pemanfaatan Bank Sampah

Jurnal IKA $\mid 12$ Tini Agustini ${ }^{1}$, I Made Tegeh ${ }^{2}$ 
performance, there are six strategies to implement waste bank as a character learning media.

Key words: waste bank, media, character education

\section{A. PENDAHULUAN}

Sampah adalah suatu bahan yang terbuang atau dibuang dari sumber hasil aktivitas manusia maupun proses alam yang belum memiliki nilai ekonomis (Ecolink dalam Sukatman,dkk., 1998). Sampah adalah sesuatu yang tidak berguna lagi, dibuang oleh pemiliknya atau pemakai semula (Tandjung dalam Sukatman,dkk.,1998). Sampah organik dan anorganik dapat menimbulkan permasalahan lingkungan jika tidak ditangani dengan baik. Apalagi sampah anorganik yang sangat sulit dan memerlukan waktu yang sangat lama untuk dapat diuraikan secara alami. Sampah anorganik memerlukan pengelolaan khusus. Inilah yang dilakukan oleh Bank Sampah Galang Panji, sehingga sampah anorganik seperti plastik, kaleng bekas, besi rongsokan, dan lain-lain dikelola melalui suatu manajemen tertentu yang dapat mensejahterakan masyarakat dan berdampak kepada kelestarian lingkungan.

Keberadaan sampah yang tidak dikelola dapat mengakibatkan pencemaran lingkungan. Dilain pihak, pola hidup masyarakat yang tidak peduli lingkungan seperti membuang sampah sembarangan dapat menyebabkan pendangkalan aliran sungai, pencemaran sumber air, dan pemicu banjir. Kebiasaan mencampurkan sampah kering dan basah, sampah organik dan anorganik berdampak semakin sulit pengelolaan dan penanganan sampah. Subaris dan Endah (2016) mengemukakan bahwa pengelolaan sampah merupakan hal yang penting untuk diperhatikan jika tidak ingin wilayah akan menjadi lautan sampah. Hal yang dilakukan oleh para pemuda pendiri Bank Sampah Galang Panji untuk memberdayakan masyarakat dalam penciptaan lingkungan yang bersih dan sehat patut diacungkan jempol. Keberadaan Bank Sampah Galang Panji tampaknya perlu dikaji dari perspeftif ilmu-ilmu sosial seperti sejarah, ekonomi, budaya, geografi, dan lain-lain.

Bank Sampah Galang Panji memiliki keunikan tertentu. Bank sampah ini dirintis dan dilaksanakan oleh para pemuda Dusun Kelod Kauh, Desa Panji, Strategi Pembelajaran Pemanfaatan Bank Sampah Jurnal IKA $\mid 13$ Tini Agustini', I Made Tegeh ${ }^{2}$ 
Kecamatan Sukasada. Pada umumnya para pemuda jaman sekarang memiliki rasa cuek dan ketidakpedulian terhadap kebersihan lingkungan. Mereka biasanya sibuk dengan berbagai kegiatan persekolahan, les privat, menyalurkan hobi, nongkrong, bersosialita di media sosial, jalan-jalan, main game online, dan berbagai kegiatan lainnya. Berbeda dengan pemuda pada umumnya, para pemuda perintis Bank Sampah Galang Panji rela mengorbankan waktu dan tenaga untuk berkecimpung dalam kegiatan penuh pengabdian mendirikan dan mengelola bank sampah.

Berbicara tentang bank sampah tidak akan terlepas dari istilah manajemen karena bank sampah merupakan suatu lembaga atau unit usaha yang memerlukan sistem manajerial. Dalam melaksanakan suatu kegiatan yang berhubungan dengan manajemen, maka akan berkaitan dengan teori manajemen. Intelektual Perancis Pierre Bourdieu melihat manajemen sebagai social field, yaitu sebuah arena sosiokulkural yang spesifik dimana aktor tertentu bermain dalam menciptakan konstruksi dan transformasi sosial.

Teori manajemen bisa dipahami sebagai sebuah proses sosial dan figure sosial. Sebagai proses sosial, teori manajemen adalah proses bagaimana organisasi bisa berjalan secara efektif dan efisien. Sebagai figur sosial, teori manajemen adalah kelompok sosial, biasanya terdiri dari eksekutif dan manajer, yang bekerja untuk menciptakan efektivitas dan efisiensi organisasi demi mencapai tujuan organisasi.

Keberadaan Bank Sampah Galang Panji dapat dijadikan salah satu media pendidikan karakter bagi para siswa SMP. Keberadaan para pemuda dibalik pendirian dan pengelolaan bank sampah dapat menjadi inspirasi dan suri tauladan bagi siswa SMP. Untuk itu perlu dikaji strategi-strategi pemanfaatan bank sampah sebagai media pendidikan karakter.

\section{B. METODE}

Metode penelitian yang digunakan adalah metode penelitian kualitatif dengan mendekatkan pada teknik-teknik pendekatan kualitatif. Lokasi penelitian Strategi Pembelajaran Pemanfaatan Bank Sampah 
adalah SMPN 4 Singaraja, Kabupaten Buleleng, Provinsi Bali. Informan penelitian adalah para guru dan siswa SMPN 4 Singaraja. Dalam penelitian ini sampel penelitian ditentukan berdasarkan teknik purposive sampling.

Sesuai dengan jenis penelitian ini yaitu penelitian kualitatif, maka metode pengumpulan data yang digunakan dalam penelitian ini adalah wawancara dan observasi. Data yang diperoleh dari berbagai informan melalui wawancara dan kuesioner kemudian diolah, diverifikasi sehingga diperoleh data yang objektif mengenai strategipembelajaran pemanfaatan bank sampah sebagai media pendidikan karakter dalam pembelajaran IPS di SMP. Dalam penelitian ini digunakan dua triangulasi, yaitu triangulasi data dan triangulasi metode. Pada penelitian kualitatif analisis data dilakukan pada saat pengumpulan data dan setelah pengumpulan data dalam kurun waktu tertentu. Analisis data dilakukan mengan mengikuti beberapa tahapan seperti reduksi data, menyajikan, menafsirkan, dan menarik kesimpulan.

\section{HASIL DAN PEMBAHASAN}

Melalui kuesioner para guru mengemukakan bahwa strategi yang paling mudah diterapkan, paling sesuai diterapkan di SMPN 4 Singaraja, yang berpusat pada siswa adalah strategi berkunjung ke lokasi bank sampah melalui metode karya wisata. Hal ini senada dengan yang diungkapkan oleh para siswa bahwa strategi berkunjung ke lokasi bank sampah merupakan strategi yang paling memotivasi, sesuai dengan keinginan siswa, menarik perhatian siswa, dan mengaktifkan siswa dalam pembelajaran. Pengalaman langsung dan riil, pemahaman yang lebih mudah, serta mudah dilakukan menjadi alasan guru dan siswa memilih metode karya wisata untuk mempelajari bank sampah. Lokasi Bank Sampah Galang Panji yang tidak terlalu jauh dari SMPN 4 Singaraja (lebih kurang $3 \mathrm{Km}$ ) dan banyaknya siswa SMPN 4 Singaraja yang berasal dari Panji menjadi pertimbangan lain mereka memilih strategi ini.

Selanjutnya bagi guru dan siswa strategi yang paling sulit dilakukan adalah pemberian tugas kelompok untuk membuat film dokumenter/video tentang Strategi Pembelajaran Pemanfaatan Bank Sampah 
bank sampah. Alasan yang dikemukakan oleh mereka adalah keterampilan pembuatan video rendah, sarana kurang mendukung, dan membutuhkan waktu yang banyak, serta biaya yang besar dalam meproduksi film atau video tentang bank sampah.

Pendidikan karakter dimaknai sebagai pendidikan yang mengembangkan nilai-nilai karakter pada peserta didik sehingga mereka memiliki nilai dan karakter sebagai dirinya, menerapkan nilai-nilai tersebut dalam kehidupan sehari hari, sebagai anggota masyarakat dan warga negara yang religious, nasionalis, produktif, dan kreatif (Zubaedi, 2011:17). Secara garis besar nilai dibagi dalam dua kelompok yaitu nilai nurani dan nilai memberi. Nilai nurani merupakan nilai yang bersumber dari dalam diri manusia yang berkembang menjadi perilaku seseorang dan cara bagaimana memperlakukan seseorang. Yang masuk ke dalam hati nurani, misalnya kejujuran, keberanian, cinta damai, disiplin, tahu diri, dan lain sebagainya. Nilai memberi yaitu nilai yang dipraktikkan atau diberikan yang kemudian diterima sebanyak yang diberikan. Seperti setia, dapat dipercaya, dihormati, cinta kasih, baik hati, ramah, dan lain sebagainnya (Elmubarok, 2009).

Pendidikan karakter merupakan suatu sistem penanaman nilai-nilai karakter kepada warga sekolah yang meliputi komponen pengetahuan, kesadaran atau kemauan dan tindakan untuk melaksanakan nilai-nilai tersebut baik dalam hubungannya dengan Tuhan Yang Maha Esa (TYME), diri sendiri, sesama, lingkungan, maupun kebangsaan, sehingga menjadi manusia seutuhnya (manusia Pancasilais). Pendidikan karakter bukanlah proses pembelajaran yang menghafalkan konsep, teori dan dalil yang akan keluar dalam ujian akhir sekolah atau ujian akhir nasional serta teknik-teknik menjawabnya, akan tetapi merupakan pembiasaan-pembiasaan untuk berbuat baik, pembiasaan untuk berlaku jujur, kesatria, malu berbuat curang, malu bersikap malas, malu membiarkan lingkungannya kotor (Adiani dalam Suastika, 2017).

Karakter tidak terbentuk secara instan, tetapi harus dilatih dan dibiasakan secara berkesinambungan agar mencapai bentuk dan kekuatan yang ideal sebagai mana tujuan masyarakat, bangsa dan negara. Pembiasaan akan sangat baik dan 
berdaya guna bila dilakukan dari lingkungan, keluarga, sekolah dan masyarakat, bangsa dan negara. Dalam proses pendidikan, pembentukan karakter tidaklah dibebankan hanya pada satu atau dua mata pelajaran saja, akan tetapi diintegrasikan pada semua mata pelajaran.

\section{SIMPULAN DAN SARAN}

Pengimplementasian strategi pemanfaatan Bank Sampah Galang Panji sebagai media pendidikan karakter dalam pembelajaran IPS di SMPN 4 Singaraja dilakukan secara terintegrasi. Hal ini berarti bahwa guru IPS perlu memadukan konten dan muatan karakter dalam pembelajaran IPS di SMP. Pengelolaan atau manajemen kelas yang baik wajib dilakukan oleh guru agar pembelajaran yang mengintegrasikan konten dan muatan karakter dapat berjalan secara efektif. Istilah manajemen berasal dari bahasa Italia "maneggiare" berarti "mengendalikan". Dalam bahasa Perancis manajemen berasal dari kata "management" yang berarti "seni melaksanakan dan mengatur". Pengaturan yang dilakukan melalui proses aktivitas dan diatur berdasarkan urutan dan fungsinya dinamakan manajemen (Effendi, 2015). Menurut Gibson, dkk. (1996) sifat pekerjaan manajemen ialah mengkoordinasikan pekerjaan orang lain dengan melaksanakan empat fungsi manajemen yaitu perencanaan, pengorganisasian, pengarahan, dan pengontrolan (planning, organizing, directing, and controlling).

Strategi yang dapat dilakukan untuk pengimplemenntasian bank sampah sebagai media pendidikan karakter ada enam, yakni: (a) memanfaatkan media video pembelajaran tentang Bank Sampah Galang Panji dan dilanjutkan dengan diskusi atau tugas-tugas lain berkaitan dengan video tersebut; (b) memanfaatkan media foto tentang aktivitas para pemuda dalam menjalankan tugas mengelola Bank Sampah Galang Panji dan dilanjutkan dengan Focus Group Discussion tentang foto tersebut dikaitkan dengan karakter para pemuda tersebut; (c) mengundang narasumber salah seorang pemuda pendiri Bank Sampah Galang Panji untuk memberikan ceramah dan motivasi kepada para siswa di kelas; (d) para siswa diajak secara bersama-sama berkunjung ke lokasi Bank Sampah 
Galang Panji melalui metode karya wisata; (e) para siswa ditugaskansecara berkelompok membuat laporan kunjungan ke Bank Sampah Galang Panji; dan (f) secara berkelompok siswa diberi proyek membuat film dokumenter atau video tentang Bank Sampah Galang Panji. Menurut pendapat para guru dan siswa SMPN 4 Singaraja, dari keenam strategi tersebut strategi keempat yakni mengajak siswa berkunjung ke lokasi Bank Sampah Galang Panji merupakan strategi yang paling mudah dilakukan, paling menarik, memotivasi siswa untuk belajar, dan pembelajaran berpusat pada siswa. Selanjutnya, para guru dan siswa menyatakan bahwa strategi yang paling sulit diterapkan adalah strategi menugaskan siswa mengerjakan proyek pembuatan film dokumenter atau video tentang Bank Sampah Galang Panji.

\section{DAFTAR PUSTAKA}

Effendi, U. 2015. Asas Manajemen. Jakarta: Rajawali Pers.

Elmubarok, Z. 2009. Membumikan Pendidikan Nilai: Mengumpulkan yang Terserak, Menyambung yang Terputus, dan Menyatukan yang Tercerai. Bandung: Alfabeta.

Gibson, J. L., et al. 1996. Organisasi, Perilaku, Struktur, dan Proses. Alih Bahasa oleh Nunuk Andiarni, jilid 1 dan 2. Jakarta: Binarupa Aksara.

Suastika, I N. 2017. Memperkuat Pancasila sebagai Karakter Bangsa dalam Masyarakat Ekonomi ASEAN. Orasi Ilmiah disampaikan pada Dies Natalis Universitas Pendidikan Ganesha ke-24.

Subaris, H. dan Dwi Endah. 2016. Sedekah Sampah. Yogyakarta: Parama Publishing and Co.

Sukatman, dkk. 1998. Lingkungan Hidup untuk Sekolah Menengah Kejuruan. Malang: Indah Offset.

Zubaedi. 2013. Desain Pendidikan Karakter. Jakarta: Kencana Prenada Media Group. 